\title{
PENINGKATAN KELARUTAN EKSTRAK DAN FRAKSI BUAH LIBO (FICUS VARIEGATA BLUME) DENGAN PENGARUH PENAMBAHAN KOSOLVEN
}

\author{
Bravo Prisukarno ${ }^{1}$, Aditya Fridayanti ${ }^{1}$, Sabaniah Indjar Gama ${ }^{1,2}$, Rolan Rusli ${ }^{1,2, *}$ \\ ${ }^{1}$ Laboratorium Penelitian dan Pengembangan Kefarmasian "Farmaka Tropis", \\ Fakultas Farmasi, Universitas Mulawarman, Samarinda, Indonesia \\ ${ }^{2}$ Kelompok Bidang Ilmu Kimia Farmasi, Fakultas Farmasi, \\ Universitas Mulawarman, Samarinda, Indonesia \\ *Email: rolan@farmasi.unmul.ac.id
}

\begin{abstract}
ABSTRAK
Telah dilakukan penelitian peningkatan kelarutan ekstrak dan fraksi buah Libo (Ficus variegata Blume) dengan pengaruh penambahan kosolven trietanolamin, gliserin dan propilenglikol. Penelitian ini bertujuan untuk mencari kosolven terbaik yang dapat meningkatkan kelarutan optimal ekstrak dan fraksi buah Libo (Ficus variegata Blume) sehingga dapat digunakan untuk berbagai jenis formulasi. Penambahan kosolven trietanolamin, gliserin dan propilenglikol dapat mempengaruhi tingkat kelarutan ekstrak dan fraksi buah Libo (Ficus variegata Blume).
\end{abstract}

Kata Kunci: Kelarutan, Kosolven, Trietanolamin, Gliserin, Propilenglikol

DOI: https://doi.org/10.25026/mpc.v7i1.289

\section{PENDAHULUAN}

Saat ini semakin banyak bahan alam yang diformulasikan menjadi sediaan obat dengan aktivitas farmakologi melalui berbagai tahapan pengujian. Berbagai bentuk sediaan dapat ditemukan dan disukai oleh masyarakat karena efek sampingnya yang lebih ringan dibandingkan obat-obatan kimiawi (Nursal, dkk., 2012).

Zat aktif yang mempunyai kelarutan kurang baik bisa berpengaruh terhadap kadar obat dalam sediian sehingga dapat diasumsikan bahwa semakin tinggi kelarutan maka kadar zat aktif semakin meningkat. Faktor kelarutan dan kestabilan dapat diperkirakan, sedangkan karakteristik rasa dan organoleptik lain masih tergantung pada faktor subjektif jadi formulasi suatu sediaan memerlukan penggabungan nilai ilmiah dan estetika (Lachman,dkk.,2007).

Tanaman obat telah dimanfaatkan secara luas namun Manfaat tradisional buah tumbuhan Libo ( $F$. variegata) tidak banyak dikenal, kecuali beberapa spesies yang termasuk genus Ficus di antaranya sebagai obat diare, sedangkan daunnya digunakan untuk membersihkan selaput mata. Pemanfaatan tumbuhan Libo khususnya buah dapat saja dilakukan dalam bidang farmasi karena ciri khas potensi farmasi dari bahan alam adalah terkait dengan obat, makanan-minuman fungsional, serta sebagai kosmetik sehat. Potensi tersebut merupakan hal penting dalam bidang farmasi misalnya sifat 
toksik berpotensi sebagai obat kanker dengan prinsip dasar pembunuh sel (kemoterapi), sifat toksik sebagai antimikroba, pestisida (insektisida, larvasida, bakterisida, fungisida, fisisida), dan lain-lain (Rijai, 2014).

Semua bagian dari libo diduga memiliki potensi aktivitas, karena diketahui mengandung metabolit sekunder berupa flavonoid, alkaloid, steroid, terpenoid, saponin dan fenol (Febrina, 2015). Potensi aktivitas pada bagian daun baik pada ekstrak maupun berbagai fraksi seperti yang telah dilaporkan oleh Cahya (2016), Novitasari (2016), Rusli (2016) dan Nurtiwi (2016), pada bagian kulit batang seperti dilaporkan oleh Utami (2016) dan Saleh (2016), serta pada bagian buah Ningsih (2016) dan isolatnya (Rusli, 2019).

\section{METODE PENELITIAN}

\section{Alat dan Bahan}

Alat yang digunakan yaitu rotary evaporatory, destilator, alat-alat kaca dan non kaca. Bahan yaitu buah tumbuhan Libo, metanol, n-heksan, etil asetat, nbutanol, aquades, trietanolamin, gliserin dan propilenglikol.

\section{Prosedur Kerja}

Sampel buah Libo (Ficus variegata Blume) dibuat menjadi simplisia kemudian diekstraksi menggunakan pelarut n-heksan selama 6 hari kemudian dilanjutkan menggunakan menggunakan pelarut metanol selama 2 hari pada suhu kamar (Ningsih, 2016). Kemudian maserat dipekatkan menggunakan rotary evaporatory, ekstrak kasar metanol difraksi menggunakan metode pemisahan fraksinasi cair-cair dengan menggunakan pelarut n-heksan, etil asetat dan n-butanol sehingga diperoleh ekstrak masingmasing fraksi. Hasil ekstrak dan masingmasing fraksi dilakukan pengujian kelarutan. Pengujian kelarutan dilakukan menggunakan aquades, trietanolamin, gliserin dan propilenglikol.

\section{HASIL DAN PEMBAHASAN}

Uji kelarutan dilakukan dengan menggunakan ekstrak dan fraksi buah Libo (Ficus variegata Blume) sebanyak 10 mg. Berdasarkan uji kelarutan diperoleh dengan hasil pada ekstrak metanol, fraksi n-heksan dan fraksi etil asetat praktis tidak larut dalam pelarut air, pada fraksi n-butanol larut dalam pelarut air dan pada fraksi air sangat mudah larut dalam pelarut air.

Uji kelarutan menggunakan penambahan 3 kosolven yang sering digunakan dalam formulasi sediaan yaitu trietanolamin, gliserin dan propilenglikol diperoleh hasil kelarutan pada ekstrak metanol dengan penambahan kosolven trietanolamin lebih baik dibandingkan dengan kosolven gliserin dan propilenglikol serta pelarut air dimana ketiganya memperoleh hasil kelarutan yang sama dengan hasil istilah kelarutan secara berurutan yaitu larut > praktis tidak larut $\geq$ praktis tidak larut $\geq$ praktis tidak larut seperti yang terlihat pada tabel 1 .

Pada fraksi n-heksan dengan penambahan kosolven trietanolamin dan kosolven gliserin lebih baik dibandingkan dengan kosolven propilenglikol dan lebih baik dibandingkan pelarut air dengan hasil istilah kelarutan secara berurutan yaitu larut $\geq$ larut $>$ agak sukar larut $>$ praktis tidak larut seperti yang terlihat pada tabel 1 .

Pada fraksi etil asetat dengan penambahan kosolven trietanolamin lebih baik dibandingkan dengan kosolven gliserin dan propilenglikol serta pelarut air dimana ketiganya memperoleh hasil kelarutan yang sama dengan hasil istilah kelarutan secara berurutan yaitu agak sukar larut $>$ praktis tidak larut $\geq$ praktis tidak larut $\geq$ praktis tidak larut seperti yang terlihat pada tabel 1 .

Pada fraksi n-butanol dengan penambahan kosolven gliserin lebih baik dibandingkan dengan kosolven propilenglikol dan pelarut air dan lebih baik dibandingkan dengan kosolven 
gliserin dan mudah larut dengan trietanolamin dengan hasil istilah kelarutan secara berurutan yaitu mudah larut $>$ larut $\geq$ larut $>$ agak sukar larut seperti yang terlihat pada Tabel 1 .

Pada fraksi air larut dengan penambahan kosolven gliserin dan pelarut air lebih baik dibandingkan dengan kosolven trietanolamin dan propilenglikol dengan hasil istilah kelarutan secara berurutan yaitu sangat mudah larut $\geq$ sangat mudah larut $>$ mudah larut $\geq$ mudah larut seperti yang terlihat pada Tabel 1 .

Tabel 1. Hasil kelarutan dan penimbangan sebanyak 1 ekstrak dan 4 jenis fraksi yang dikelompokkan menjadi 4 kelompok besar dengan menggunakan pelarut air, kosolven trietanolamin, gliserin dan propilenglikol.

\begin{tabular}{cccccccc}
\hline \multirow{2}{*}{ Sampel } & \multicolumn{3}{c}{ Hasil Kelarutan } & \multicolumn{3}{c}{ Hasil Penimbangan } \\
\cline { 2 - 8 } & Air Suling & Trietanolamin & Gliserin & Propilenglikol & Trietanolamin (g) & Gliserin (g) & Propilenglikol (g) \\
\hline Ekstrak Metanol & PTL & L & PTL & PTL & 0,1779 & 1,3676 & 1,4079 \\
Fraksi N-Heksana & PTL & L & L & ASL & 0,2328 & 0,2497 & 0,3249 \\
Fraksi Etil Asetat & PTL & ASL & PTL & PTL & 0,3979 & 1,5612 & 1,1572 \\
Fraksi N-Butanol & L & ASL & L & ML & 0,3232 & 0,2621 & 0,0118 \\
Fraksi Air & SML & ML & SML & ML & 0,0103 & 0,0092 & 0,0109 \\
\hline Keterangan : SML = Sangat Mudah Larut & \multicolumn{2}{c}{ ML = Mudah Larut } & & L = Larut \\
\multicolumn{2}{r}{ ASL = Agak Sukar Larut } & \multicolumn{2}{c}{ SSL = Sangat Sukar Larut } & & PTL = Praktis Tidak Larut
\end{tabular}

Untuk tujuan farmasetik banyak digunakan zat yang mengandung gugus hidroksil-karboksil, seperti alkohol monovalen ataupun polialkohol senyawa ester dan eter sebagai peningkat kelarutan seperti trietanolamin, gliserin dan propilenglikol dimana bahan dengan gugus molekul polar yang sangat hidrofil mampu meningkatkan kelarutan zat dalam air. Dimana zat-zat tersebut bekerja dengaan mekanisme yang disebut sebagai efek hidrotropi yang berdasarkan adanya aktivitas ikatan jembatan hidrogen, sebagian yang lain atas pembentukan kompleks dan penurunan tegangan permukaan. Menurut Nursal, dkk diketahui bahwa senyawa yang mampu membentuk jembatan hidrogen dan mampu menggantikan jembatan hidrogen yang terdapat pada molekul air dapat mempengaruhi kelarutan bahkan struktur (Nursal, dkk., 2012).

Dari hasil uji kelarutan didapatkan hasil yaitu trietanolamin merupakan kosolven terbaik yang dapat digunakan untuk meningkatkan kelarutan ekstrak dan fraksi buah Libo (Ficus variegata Blume).
Trietanolamine, gliserin dan ropilenglikol merupakan golongan alkohol bervalensi banyak yang sering digunakan sebagai pengawet, antimikroba, disenfektan, humektan, plastizer, pelarut, agen penstabil dan peningkat kelarutan pada pembuatan sediaan farmasi.

Penggunaan kosolven trietanolamin, gliserin dan propilenglikol terbukti dapat membentuk ikatan hidrogen, pembentukan kompleks dan menurunkan tegangan permukaan, sehingga mampu meningkatkan kelarutan ekstrak dan fraksi buah Libo (Ficus variegata Blume).

\section{KESIMPULAN}

Penambahan

kosolven trietanolamin, gliserin dan propilenglikol dapat meningkatkan kelarutan ekstrak dan fraksi buah Libo (Ficus variegata Blume).

\section{DAFTAR PUSTAKA}

[1] Ningsih, B.A., Rahmadani, A., Fadraersada, F., Rusli, R., 2016. Aktivitas Antibakteri dan 
Antioksidan Isolat Fraksi Etil Asetat Buah Libo (Ficus variegata Blume.). Prosiding Seminar Nasional Tumbuhan Obat Indonesia (TOI) Ke50. Samarinda. Indonesia. ISBN 987602-73052-1-2

[2] Utami, D.N., Rahmadhani, A., Fadraersada, F., Rusli, R., 2016. Aktivitas Antioksidan Kulit Batang Libo (Ficus variegata Blume). Prosiding Seminar Nasional Tumbuhan Obat Indonesia (TOI) Ke50. Samarinda. Indonesia. ISBN $987-$ 602-73052-1-2

[3] Cahyadi, D.D., Febrina, L., Rusli, R., 2016. Aktivitas Antioksidan Ekstrak Daun Libo (Ficus variegate Blume) dengan Berbagai Metode Ekstraksi. Prosiding Seminar Nasional Tumbuhan Obat Indonesia (TOI) Ke50. Samarinda. Indonesia. ISBN 987602-73052-1-2

[4] Febrina, L., Rusli, R., Muflihah, F., 2015. Optimalisasi Ekstraksi dan Uji Metabolit Sekunder Tumbuhan Libo (Ficus variegate Blume). J. Trop. Pharm. Chem., 3 (2), 74-81.

[5] Novitasari, M.R., Febrina, L., Agustina, R., Rahmadani, A., Rusli, R., 2016. Analisis GC-MS Senyawa Aktif Antioksidan Fraksi Etil Asetat Daun Libo (Ficus variegata Blume.). Jurnal Sains dan Kesehatan. 1 (5), 221-225.

[6] Nursal, F. K., Arsyadi dan Wawan Gunawan., 2012. Kombinasi Pelarut Campur Polietilenglikol 400 dan Propilenglikol untuk Meningkatkan Kelarutan Kurkuminoid dalam
Larutan Ekstrak Temulawak (Curcuma xanthorriza. Roxb). FARMASAINS. 6. 267-2.

[7] Nurtiwi, O.E., Rahmawati, D., Rusli, R., 2016. Aktivitas Antioksidan Fraksi n-Butanol Tanaman Libo (Ficus variegate Blume). Prosiding Seminar Nasional Tumbuhan Obat Indonesia (TOI) Ke-50. Samarinda. Indonesia. ISBN 987-602-73052-1-2

[8] Rijai, L., 2013. Potensi Tumbuhan Libo (Ficus variegata, Blume) Sebagai Sumber Bahan farmasi Potensial. J. Trop. Pharm. Chem. 2. (3). 166-179.

[9] Saleh, R.A., Rahmadani, A., Febrina, L., Rusli, R., 2016. Aktivitas Antibakteri Kulit Batang Libo (Ficus variegate Blume). Prosiding Seminar Nasional Tumbuhan Obat Indonesia (TOI) Ke-50. Samarinda. Indonesia. ISBN 987-602-73052-1-2

[10]Rusli, R., Hardina, M.P., Muflihah, F., Rahmadani, A., 2015. Profil Kromatografi Senyawa Aktif Antioksidan dan Antibakteri Fraksi n-Heksana Daun Libo (Ficus variegata Blume). J. Trop. Pharm. Chem, 3 (2), 124-130.

[11]R Rusli, BA Ningsih, A Rahmadani, L Febrina, V Maulidya, J Fadraersada, 2019. Isolation and Antioxidant and Antibacterial Activity of Flavonoid from Ficus variegate Blume. Indonesian Journal of Chemistry 19 (2), 538-543

[12]Lachman, L., Lieberman, H., A dan Kaning, J., L. 2007. Teori dan Praktek Farmasi Industri. Jakarta. 